\title{
Investigation of the Acceptability and Effectiveness of Academic Podcasts to College Students' Scholastic Performance in Science
}

\author{
Ernie C. Avila ${ }^{1 *}$ and Mary Kris S. Lavadia ${ }^{2}$ \\ Polytechnic University of the Philippines-Ragay Branch, 4410, Philippines; \\ ernieavila@ymail.com, krizzylavadia@gmail.com
}

\begin{abstract}
Objectives: To evaluate the Acceptability and Effectiveness of Academic Podcasts in Science, an experiment was carried out to determine its effects in improving the academic performance of Second Year BSOA and BSBA students of PUPRagay. Methods/Statistical Analysis: The study developed a podcasts as teaching strategy in Biology for Reproduction, Respiratory system, and Heredity and Genetics that was evaluated by 10 science teachers as Jurors; and was laid out in quasi-experimental research design employing pre-test post-test control group, and taught in the following treatments: $\mathrm{n}_{1}$ (Control group) -50 students; $\mathrm{n}_{2}$ (experimental group) -50 students both with 25 males : 25 female students. Findings: Findings revealed that the researchers-made academic podcasts were Highly Acceptable in terms of objectives, content, language-level, time frame, and assessment; there was a highly significant improvement in the performance of the experimental group $(Z=10.980>0.001)$; and their performance highly differed with the control group $(Z=1.6606>0.001)$. The paper concludes that it can improve the academic performance compared with the students who utilized regular textbooks that can be used to change the shift toward e-learning in the Philippines basic education setting. The facts that improved academic performance of students was observed proves that academic podcasts can be used in teaching college science subjects, which points to more self-paced and self-directed learning which depend highly on the students' exposure to the said technology. Application/Improvements: Generally, the use of academic podcasts in teaching tertiary science could highly improve students' retention and comprehension, making them more competitive and knowledgeable of the important science concepts.
\end{abstract}

Keywords: Academic Podcasts, Development, Acceptability and effectiveness of academic podcasts, Tertiary Science

\section{Introduction}

The ultimate goal of Department of Education is to produce quality individuals who can compete globally in terms of knowledge 1 through the $\mathrm{K}$ to 12 Curriculum that envisions the development of scientifically, technologically and environmentally literate and productive members of the society ${ }^{2}$. Development and validation of quality instructional material's policy implications are that quality materials must be developed, allocated, and constructed. They must be made suitable to the competencies of the curriculum and should be made correctly for their intended learners ${ }^{3}$. An ideal teacher gives concern to the effective delivery of the lessons and put high values on the learning capabilities of his learners. Hence, teacher must employ variety of methodologies, techniques and teaching strategies that can give to the students the hundred percent learning and acquisition of new skills. Therefore, by using podcasts in teaching is well suited as a delivery mechanism for recorded classroom lectures that can improve students' scholastic achievement ${ }^{\underline{4}}$ since its implication is more of personal constructivist perspective on which learning can be facilitated by teachers who challenge student conceptions and involve them actively in the teaching-learning process by providing stimulating and motivating experiences, emphasizing that learners need to be actively involved, to reflect on their learning and make inferences, and to experience cognitive conflict $\stackrel{5}{\text {. }}$.

${ }^{*}$ Author for correspondence 
It supports the Basic Education in the Philippines since it faces a lot of challenges due to the changes in the curriculum, limited IT resources and spiraling changes and improvement becomes overwhelming for administrators and teachers $s^{6,7}$. Also in the traditional classroom setting, the teacher usually talks more than the student and the learning process is more of group dynamics rather than self-paced process $s^{8}$. Podcasting should be more advocated in the country since it was utilized in 2016 in the United States $^{2}$ there were at least 150 million who watched podcasts. $27 \%$ of them are within the age of $12-24,24 \%$ of them were men and $18 \%$ of them were women, and it was averaged that $40 \%$ of the respondents were listening and watching to it within 1 to 3 hours per week. Hence, can be used as teaching strategy for the younger generation. By using this technology in teaching can make learning personalized, more interactive, and more dynamic since the emergence of new media that streamlined the various aspects of teaching pedagogy and affects it positively ${ }^{10}$. Also, students learn independently when their teachers use podcasts ${ }^{11}$ hence, inspiring them to develop critical thinking of reflection in the given topics ${ }^{12}$.

Podcasts is a mobile learning technique that can help the grade 10 students in performing better in Biology $y^{13}$. Likewise, it can accommodate learners who prefer visual learning that seem to be more beneficial if used in teaching if compared to books ordinarily used by the students $\frac{14,15}{}$. Secondly, its low cost can help students develop their writing skills that promote retention and application ${ }^{10}$. Furthermore, e-learning tools have gained superior achievement after they were given supplementary podcasts after the lecture parts thereby improving their knowledge acquisition compared to traditional methods of transferring knowledge via textbooks ${ }^{14}$.

In the attempt to understand more about the educational methods and student's priorities about online instruction, podcasts lead to a new era of knowledge and information instruction ${ }^{13}$. Moreover as the podcasts are now becoming commercially and freely available from private and public media companies and independent broadcasters, information in almost all topics becomes more accessible $\underline{\underline{12}}$, hence can be answer to some challenges faced by the public school teachers who are less qualified to teach, the lack of instructional materials, inadequate facilities and lack of training for professional growth hindered them to perform at their best $t^{16}$ that are faced by education sectors to become modernize ${ }^{4}$ since ICT in education is undeniably having produced significant positive impact. ICT is changing the developed world's attitudes and approaches to education ${ }^{17}$. Furthermore, its acceptability in teaching and learning process is now becoming improved as it supports the affective and cognitive aspects of learning 18 . Thus, the positive effects of utilizing podcasts together with textbooks were emphasized since books can guide the learners in the learning process while the podcasts can enhance the learning process suitable to the low and midorder learning process under the Bloom's taxonomy ${ }^{19}$.

The academic performance of students can be improved by using the podcasts in teaching and learning process since the content acquisition of learners become self-paced, self-guided, hence enabling students to fully participate and engage in class discussion and control how much they want to learn from viewing ${ }^{20}$. As the podcasts support the use of the new digital and communication features, it creates interactive and open digital learning thereby promoting higher better scholastic achievement of the students learning environment $\underline{21}$.

Investigating the acceptability and effectiveness of the podcasts is imperative since teachers hold different perspectives, expectations, acceptance, utilization, and readiness in technology utilization thus, its addition to classroom practices becoming a substantial and addition to teaching practices and rearranging the fundamentals of school structures. Also, by utilizing podcasts in teaching science concepts provides the opportunity for better academic performance since in podcasting can capture fundamental topics and can be used to adjust to the students' learning style to provide a variety of learning opportunities that make teachers create attractive and versatile teaching strategy. Also, student's learning is affected due to its ease of use, usefulness, image, and enjoyment. Thus, understanding and evaluation of this technology along adoption, support, and effective earning will help to identify shortcomings and gaps ${ }^{22-26}$. Using the podcast in teaching is advantageous since it is a worthwhile experience that educators can use to enhance student learning as well as to develop the skills needed for the $21^{\text {st }}$ century. Its application is increasing worldwide since schools and students are already, in general, up-todate with its functionality, which will often make a teacher's implementation of podcasting easier than one may expect ${ }^{27}$. 


\section{Materials and Methods}

\subsection{Experimental Area}

The study was conducted at Polytechnic University of the Philippines-Ragay Branch, Ragay Philippines where the researcher is currently teaching.

\subsection{Research Subjects}

The research subjects were the 50 second year students taking up Bachelor of Science in Office Administration and 50 second year students taking Bachelor of Science in Business Administration that were handled by the researcher as their instructor in College Biology subject.

\subsection{Experimental Design, Treatments and}

\section{Layout}

The experiment was laid out in a pre-test post-test control group design. This study was composed of 2 research subjects and taught within 1 semester. The following are the treatments: Research Subject Group 1- BSBA (Experimental, taught with Academic Podcasts) and Research Subject Group 2- BSOA (Control group, taught using ordinary instruction).

\subsection{Podcast Development}

Podcasts were developed by the researcher following the guidelines $\frac{28,29}{}$. The topics of the researcherdeveloped podcasts focused on coordinated functions of reproductive system, endocrine and nervous system, heredity, biodiversity, evolution and ecosystem of College Biology Subject, AY 2017-2018. The podcasts were developed using the Microsoft Office 2013 Power point presentation. The researcher utilized the common laptop audio and microphone devices. The power point presentation was later converted into video presentation on which audio recording was integrated.

\subsection{Data Gathered}

The acceptability and effectiveness of the academic podcasts will be measured using survey questionnaire given to the science teachers that served as the Jurors and pre-test and post-tests given to the research subjects before and after the treatment as shown in Table 1.
Table 1. Rating Scale used for acceptability evaluation of the researcher-developed podcasts

\begin{tabular}{|l|l|}
\hline Scale & Verbal Interpretation \\
\hline $4.21-5.00$ & Outstanding \\
\hline $3.21-4.20$ & Very Satisfactory \\
\hline $2.41-3.20$ & Satisfactory \\
\hline $1.81-2.40$ & Fair \\
\hline $1.00-1.80$ & Needs Improvement \\
\hline
\end{tabular}

\subsection{Statistical Treatment}

Weighted Mean was used for the acceptability and Z-test for dependent was utilized to gauge the significant difference of the post-test scores of the research subjects and Z-test for independent sample was used to determine the significant improvement from pre-test to post-test scores of the research subjects.

\section{Results and Discussion}

Acceptability of the Academic Podcast in terms of Objectives

The science teachers-respondents evaluated the acceptability of the objectives of the podcasts as Very Satisfactory. The objectives of the podcasts are in line with the Philosophy, Vision, Mission and Goals of CHED (4.50) has the highest acceptability mean $\frac{30,31}{}$, while objectives are brief, concise and can be accomplished within a period (4.20) ranked third and they are in accordance with three domains of learning by Bloom and they are clearly stated ${ }^{32}$. This implies that the objectives set by the teacher-researcher for his developed podcasts suit

Table 2. Acceptability of the academic podcast in terms of objectives

\begin{tabular}{|c|c|c|c|}
\hline Objectives & WM & VI & Rank \\
\hline $\begin{array}{l}\text { 1. The objective are in line with the } \\
\text { Philosophy, Vision, Mission and } \\
\text { Goals of CHED. }\end{array}$ & 4.5 & $\mathrm{E}$ & 1 \\
\hline $\begin{array}{l}\text { 2. They are brief, concise and can be } \\
\text { accomplished within a period. }\end{array}$ & 4.2 & VS & 3 \\
\hline $\begin{array}{l}\text { 3. They are in accordance with three } \\
\text { domains of learning by Bloom. }\end{array}$ & 4.1 & VS & 4.5 \\
\hline 4. They are clearly stated. & 4.1 & VS & 4.5 \\
\hline $\begin{array}{l}\text { 5. Objectives are parallel to the target } \\
\text { of the subject itself. }\end{array}$ & 4.4 & VS & 2 \\
\hline Weighted Mean & 4.26 & VS & \\
\hline
\end{tabular}


to the standard set by the jurors and by the Department of Education as well. It connotes that the objectives of the researcher-developed podcasts are appropriate to the level of competencies ${ }^{\frac{33}{3}}$ as shown in Table 2.

\section{Acceptability of the Academic Podcast in terms of Contents}

The respondent's evaluation on the acceptability of the podcasts reveals that its content was Very Satisfactory. The different activities are applicable for College Students (4.70) has the highest acceptability meanwhile Activities are needed by the students to understand concepts properly (4.20) has the lowest mean that resulted to a general average weighted mean of 4.50 or Excellent. This implies that the content of the podcasts put by the teacher-researcher suit to the needs of the students and conforms with the Commission on Higher Education Competencies as well. It connotes that the podcasts developed by the researcher was highly acceptable and very much appropriate to be used by the College students in Science as shown in Table 3.

Table 3. Acceptability of the academic podcast in terms of contents

\begin{tabular}{|l|c|c|c|}
\hline Contents & WM & VI & Rank \\
\hline $\begin{array}{l}\text { 1. The different activities are applicable } \\
\text { for College Students. }\end{array}$ & 4.7 & $\mathrm{E}$ & 1 \\
\hline $\begin{array}{l}\text { 2. Contents are simple, concise, and will } \\
\text { provide an avenue for learning. }\end{array}$ & 4.6 & $\mathrm{E}$ & 2.5 \\
\hline $\begin{array}{l}\text { 3. College Students will be familiar with } \\
\text { basic concepts before proceeding to } \\
\text { the next topic. }\end{array}$ & 4.4 & VS & 4 \\
\hline $\begin{array}{l}\text { 4. Prior Concepts will serve as } \\
\text { additional inputs for the College } \\
\text { Students as they go on with higher } \\
\text { Sciences. }\end{array}$ & 4.6 & $\mathrm{E}$ & 2.5 \\
\hline $\begin{array}{l}\text { 5. Activities are needed by the students } \\
\text { to understand concepts properly. }\end{array}$ & 4.2 & $\mathrm{VS}$ & 5 \\
\hline \multicolumn{1}{|c|}{ Composite Mean } & 4.50 & $\mathrm{E}$ & \\
\hline
\end{tabular}

\section{Acceptability of the Academic Podcast in terms of Assessment}

The assessment of the teacher-respondents on the assessment components of the podcasts shows that the questions will develop Higher Order Thinking Skills of Students (4.60) has the highest weighted meanwhile indicators assessment activities are accord to the objectives of the podcast and questions are correct and follows Bloom's Cognitive Domain (4.10). The findings imply that the assessment activities provided in the podcasts is appropriate to the students and can develop their higher order thinking skills. It is challenging and accordance with the established target competencies set by the College Curriculum since assessment is important as part of the management of teachers to measure teaching-learning process ${ }^{34}$ as shown in Table 4.

Table 4. Acceptability of the academic podcast in terms of assessment

\begin{tabular}{|l|c|c|c|}
\hline Assessment & WM & VI & Rank \\
\hline $\begin{array}{l}\text { 1. Questions will develop Higher } \\
\text { Order Thinking Skills of Students. }\end{array}$ & 4.6 & E & 1 \\
\hline $\begin{array}{l}\text { 2. Assessment activities are accord to } \\
\text { the objectives of the podcast. }\end{array}$ & 4.1 & VS & 4.5 \\
\hline $\begin{array}{l}\text { 3. Questions are correct and follows } \\
\text { Bloom's Cognitive Domain. }\end{array}$ & 4.1 & VS & 4.5 \\
\hline $\begin{array}{l}\text { 4. Questions are clearly understood by } \\
\text { College Students. }\end{array}$ & 4.4 & VS & 2 \\
\hline $\begin{array}{l}\text { 5. Assessment conforms to the } \\
\text { standard set by CHED on the } \\
\text { Assessment Guidelines for College } \\
\text { Curriculum. }\end{array}$ & 4.3 & VS & 3 \\
\hline \multicolumn{1}{c}{ Composite Mean } & 4.30 & VS & \\
\hline
\end{tabular}

Acceptability of the Academic Podcast in terms of Language-Level

The acceptability of the podcasts as perceived by the science teachers-respondents reveals that the languagelevel of the podcasts were Very Satisfactory. The instructions are clearly stated and can be easily followed and performed (4.60) has the highest acceptability mean $\frac{35,36}{}$ and terms used in the podcast are simple (4.5) ${ }^{37}$ while the set of activities are spirally progressive (4.10) has the lowest mean $\frac{38}{}$. The findings connote that the language level of the podcasts that was developed by the researcher can be highly understood by the students and can aid the teacher in conveying thoughts and communicating the science concepts effectively in a simple but concise manner. Therefore, the podcast can aid the students in developing their science vocabulary, promotes retention and abstraction of concepts and generate improvement on their scientific understanding ${ }^{39}$ as shown in Table 5. 
Table 5. Acceptability of the academic podcast in terms of language-level

\begin{tabular}{|l|c|c|c|}
\hline Language Level & WM & VI & Rank \\
\hline $\begin{array}{l}\text { 1. Different terms in every session } \\
\text { and activities are understandable by } \\
\text { College Students. }\end{array}$ & 4.3 & VS & 4 \\
\hline $\begin{array}{l}\text { 2. Instructions are clearly stated and } \\
\text { can be easily followed and per- } \\
\text { formed. }\end{array}$ & 4.6 & E & 1 \\
\hline $\begin{array}{l}\text { 3. Activities and terms are in line with } \\
\text { the level of comprehension of the } \\
\text { College Students. }\end{array}$ & 4.5 & $\mathrm{E}$ & 2.5 \\
\hline $\begin{array}{l}\text { 4. The set of activities are spirally } \\
\text { progressive. }\end{array}$ & 4.1 & VS & 5 \\
\hline $\begin{array}{l}\text { 5. Terms used in the podcast are } \\
\text { simple. }\end{array}$ & 4.5 & $\mathrm{E}$ & 2.5 \\
\hline \multicolumn{1}{c}{ Composite Mean } & 4.40 & VS & \\
\hline
\end{tabular}

\section{Acceptability of the Academic Podcast in Terms of} Time-Frame

The data shows that the time allotment for activities are in accordance to the time frame, and the activities are within the time frame (4.50) while indicator Activities can be performed within a specified period of time (4.00). The findings imply that the activities given in the podcast can be finished within the specified working days for the Semester and can be done during and after the lecture part. Therefore, the students are structured to do their tasks included in the Podcasts to gain a meaningful learning experience in a Semester ${ }^{40}$ as shown in Table 6.

Table 6. Acceptability of the academic podcast in terms of time-frame

\begin{tabular}{|l|c|c|c|}
\hline Time-Frame & WM & VI & Rank \\
\hline $\begin{array}{l}\text { 1. Activities can be performed within a } \\
\text { specified period of time. }\end{array}$ & 4.0 & VS & 5 \\
\hline $\begin{array}{l}\text { 2. Activities can be done during the } \\
\text { lecture sessions for the particular } \\
\text { topic. }\end{array}$ & 4.4 & VS & 3.5 \\
\hline $\begin{array}{l}\text { 3. Time allotment for activities are in } \\
\text { accordance to the time frame. }\end{array}$ & 4.5 & $\mathrm{E}$ & 1.5 \\
\hline $\begin{array}{l}\text { 4. Activities are within the time frame. } \\
\text { 5. Activities can be finished within } \\
\text { 32 days. }\end{array}$ & 4.5 & $\mathrm{E}$ & 1.5 \\
\hline \multicolumn{1}{|c}{ Composite Mean } & VS & 3.5 \\
\hline
\end{tabular}

\subsection{Improvement from the Pre-test to Post- test of the Experimental group after the Utilization of Podcasts in Biology}

This objective was analyzed and discussed based on the results of pre-test to post-test results of the experimental group that utilized the researcher-developed podcasts in Science which would serve as basis for conclusions and appropriate recommendations. Based from the data presented, the Experimental Group performance highly improved after instruction and exposure to the podcasts after having a population means of 38.275 and with a computed $\mathrm{Z}$ of 10.980 higher than the tabular value of 1.6766 at 0.001 level of significance.

Based from the given results, it implies that podcasts can be used in teaching Science for College students for them to increase their knowledge and enhance their competencies in science subject that lead to better academic performance, and can transfer learning to actual lives ${ }^{41}$ as shown in Table 7.

Table 7. Improvement from Pre-test to Post-test of the Experimental group after the utilization of Podcasts in Science

\begin{tabular}{|l|c|}
\hline Indicators & \\
\hline Number of Cases & 50 \\
\hline Population mean & 38.275 \\
\hline Standard Deviation & 11.89 \\
\hline Computed $\mathrm{z}$ & 10.980 \\
\hline Tabular Value at 0.05 & 1.6766 \\
\hline Decision on Ho & Rejected \\
\hline Significance of Improvement & 0.0005 \\
\hline
\end{tabular}

\subsection{Difference from the Pre-test to Post- test of the Research Subjects after the Utilization of Podcasts in Science}

Based on the results of pre-test to post-test results of the students who those utilized the researcher-developed Podcasts in Science and those who were not given the treatment, the population mean of the control group was 30.88 which were lower than the 38.28 population mean of the experimental group. The computed $\mathrm{z}$ of the two groups arrived at 6.78 which was significantly higher than the tabula value of 1.6606 at 0.0001 level of significance. Therefore, the students' performance of the two research subjects was significantly different based from their post- 
test results. The performance of the control group in the post test is low compared to the experimental group with a high performance as shown in Table 8.

Table 8. Difference from pre-test to post-test results of the research subjects

\begin{tabular}{|l|c|c|}
\hline Indicators & $\begin{array}{c}\text { Experimental } \\
\text { Group }\end{array}$ & $\begin{array}{c}\text { Control } \\
\text { Group }\end{array}$ \\
\hline Number of Cases & 50 & 50 \\
\hline Population mean & 38.28 & 30.88 \\
\hline Standard Deviation & 5.61 & 4.03 \\
\hline Computed $z$ & \multicolumn{2}{|c|}{6.78} \\
\hline Tabular Value at 0.05 & \multicolumn{2}{|c|}{1.6606} \\
\hline Decision on Ho & \multicolumn{2}{|c|}{ Rejected } \\
\hline Significance of Difference & \multicolumn{2}{|c|}{0.0005} \\
\hline
\end{tabular}

The findings imply that there is really a need to use the strategy in Science and College Biology students to improve their performance and promote retention and improvement in their vocabulary in science and improve their higher order thinking skills ${ }^{42}$.

\subsection{Pointers on the Effective Use of the Podcasts in Science}

Based from the results presented, the researcher suggested the following pointers: For the Teachers: Use the Podcast in the motivation and assignment parts of the lessons; Provide transcription of the Podcast for the students; Post pictures and videos related to the podcast develop; Utilize the develop podcast using clear audio and video projector; Share the podcast files among the students to facilitate relearning of concepts; For the Curriculum Writers: Develop a separate learners' guide on how to use the Podcast effectively; develop a website to publish the Podcast for students' consumption; For the School Administrators: include the training on the development and testing of podcasts in the teaching of science and likewise encourage all the teachers to use the promising technology.

\section{Conclusions and Recommendations}

Based on the findings of the study, these conclusions were formulated. The set of jurors evaluated the Podcast in Science as Very Satisfactory in Objectives, Language
Level, Assessment and Time Frame while Excellent for the Content. There is a highly significant agreement on the jurors' evaluation on the acceptability of the podcasts. Also, the performance of the experimental group highly improved due to their utilization of the researcher-made podcasts while there is a highly significance of difference between the post-test scores of the experimental group who utilized the researcher-made podcasts in Science and the Control Group. And lastly, the pointers recommended by the researcher on how to effectively use the Podcasts in Science were: For the Teachers: Use the Podcast in the motivation and assignment parts of the lessons; Provide transcription of the Podcast for the students; Post pictures and videos related to the podcast develop; Utilize the develop podcast using clear audio and video projector; Share the podcast files among the students to facilitate relearning of concepts; For the Curriculum Writers: Develop a separate learners' guide on how to use the Podcast effectively; develop a website to publish the Podcast for students' consumption.

Teacher must continuously venture out on the creation and validation of instructional materials and learning strategies. However, it is recommended further that the materials must be ensured in terms of their validity by subjecting them on the content and external validity criteria. Services of the content and grammar editor must also be required to subject the medium utilized in the formulated podcasts. Experts on the instructional materials and web-based materials must be invited as critics to further improve the podcasts and the guides must be extended to the students and teachers to determine its acceptability that can be used by diverse group of learners. The study does not include the effectiveness of the podcasts as supplementary material in other topics and focus in Science, hence future study maybe conducted to gauge the amount of contribution that the podcasts in the improvement of students' performance in other subject areas in the Tertiary Curriculum of the Philippines.

\section{Acknowledgement}

The author is very grateful to the Polytechnic University of the Philippines-Ragay Branch for the approval of this study. Likewise, he is grateful to Graduate School Dean Dr. Eleanor A. Osea of University of Northeastern Philippines, Iriga City, Camarines Sur who served as his statistician. 


\section{References}

1. Our DepEd Vision, Mission, and Core Values [Internet]. [cited 2019]. Available from: https://www.teacherph.com/ deped-vision-mission/.

2. K to 12 Curriculum Guide Science [Internet]. [cited 2013 May 13]. Available from: https://www.slideshare.net/ kenjoyb/k-to-12-science-curriculum-guide.

3. Selga MCR. Instructional materials development: A work text in science, technology and society. Instructional Materials Development: A Work text in Science; 2013. p. 71-95.

4. Heilesen SB. What is the academic efficacy of podcasting? Computer Education. 2010; 55(3):1063-8.https://doi. org/10.1016/j.compedu.2010.05.002

5. Deal A. Teaching with technology podcasting. Carnegie Mellon University; 2007. p. 15.

6. Matulac MR. Experiences in Technology Integration; 2018.

7. Sobejana N. Educational technology and academic performance of students in Basic English in selected higher education institutions in Davao del Sur. International Journal of Logistics Research and Applications. 2016; 1(1):1-13.

8. Bencheva N. Learning styles and e-learning face-to-face to the traditional learning. E-learning; 2010. p. 63-7.

9. Edison Research. The Podcast Consumer; 2015. p. 28.

10. Amir Z, Ismail K, Hussin S. Blogs in language learning: Maximizing students' collaborative writing. Procedia Social Behaviour Science. 2011; 18:537-43. https://doi. org/10.1016/j.sbspro.2011.05.079

11. Lawlor B, Donnelly R. Using podcasts to support communication skills development: A case study for content format preferences among postgraduate research students. Computer Education. 2010; 54(4):962-71. https:// doi.org/10.1016/j.compedu.2009.09.031

12. Hargett JL. Podcasting in nursing education: using commercially prepared podcasts to spark learning. Teaching and Learning in Nursing. 2018; 13(1):55-7. https://doi.org/10.1016/j.teln.2017.08.003

13. Hamidi H, Chavoshi A. Analysis of the essential factors for the adoption of mobile learning in higher education: A case study of students of the University of Technology. Telemate Informatics; 2017.

14. Back DA, von Malotky J, Sostmann K, Hube R, Peters H, Hoff E. Superior gain in knowledge by podcasts versus text-based learning in teaching orthopedics: A randomized controlled trial. Journal of Surgical Education. 2017; 74(1):154-60. https://doi.org/10.1016/j.jsurg.2016.07.008. PMid:27651055

15. Bolliger DU, Supanakorn S, Boggs C. Impact of podcasting on student motivation in the online learning environment.
Computer Education. 2010; 55(2):714-22. https://doi. org/10.1016/j.compedu.2010.03.004

16. Durban JM, Catalan RD. Issues and concerns of Philippine education through the years. Asian Journal of Humanities and Social Sciences. 2012; 1(2):61-9.

17. Marcial DE, De La Rama PA. ICT competency level of teacher education professionals in the Central Visayas Region, Philippines. Asia-Pacific Journal of Regional Science. 2015; 3(35):28-38.

18. Kay RH. Exploring the use of video podcasts in education: A comprehensive review of the literature. Computer Human Behaviour. 2012; 28(3): 820-31. https://doi.org/10.1016/j. chb.2012.01.011

19. Popova A, Edirisingha P. How can podcasts support engaging students in learning activities? Procedia - Social and Behavioral Sciences. 2010; 2(2):5034-38.https://doi. org/10.1016/j.sbspro.2010.03.816

20. Lewis E, Chen DC, Relan A. Implementation of a flipped classroom approach to promote active learning in the thirdyear surgery clerkship. The American Journal of Surgery. 2017.https://doi.org/10.1016/j.amjsurg.2017.08.050. PMid:29169824

21. Wang L, Wang D, Hao L. The design and implementation of university vedio resources platform based on podcast. Procedia Engineering. 2011; 15:2186-90. https://doi. org/10.1016/j.proeng.2011.08.409

22. Moloo PK, Khedo KK, Prabhakar TV. Critical evaluation of existing audio learning systems using a proposed TOL model. Computer Education. 2018; 117:102-15.https://doi. org/10.1016/j.compedu.2017.10.004

23. Lin S, Zimmer JC, Lee V. Podcasting acceptance on campus: The differing perspectives of teachers and students. Computer Education. 2010; 68:416-28. https:// doi.org/10.1016/j.compedu.2013.06.003

24. Lonn S, Teasley SD. Podcasting in higher education: What are the implications for teaching and learning? Internet Higher Education. 2009; 12(2):88-92. https://doi. org/10.1016/j.iheduc.2009.06.002

25. Luzón JM, Letón E. Use of animated text to improve the learning of basic mathematics. Computer Education. 2015; 88:119-28. https://doi.org/10.1016/j.compedu.2015.04.016

26. Merhi MI. Factors influencing higher education students to adopt podcast: An empirical study. Computer Education. 2015; 83:32-43. https://doi.org/10.1016/j.compedu.2014. 12.014

27. Aristizabal A. Podcasting: A preliminary classroom study; 2009. p. 30-40.

28. Duffy J. How to create a podcast for e-Learning. eLearn. 2010; 11:2. https://doi.org/10.1145/1890748.1890750

29. Dugard P, Todman J. Analysis of pre-test-posttest control group designs in educational research. 
Education Psychology. 1995; 15(2):181-98. https://doi. org/10.1080/0144341950150207

30. Siegel S. Nonparametric statistics for the behavioral sciences. New York McGraw-Hill; 1956.

31. Anderson R. A parallel approach to ESAP teaching. Procedia - Social and Behavioral Sciences. 2014; 136:194202. https://doi.org/10.1016/j.sbspro.2014.05.313

32. U. of Glasgow. Performance development review guide to writing SMART objectives; 2015.

33. Tobergte DR, Wagenaar CS. 2014 Competences and learning outcomes - a panacea for understanding the (new) role of Higher Education (original source - Uni Texas Sch of Pub Health). Journal of Chemical Information and Modeling. 2013; 53(9):1689-99.

34. Janer SS, Deri RA, Dio RV, Marbella FD, Ricafort JD. Factors on enhancing competitive edge and attributes of graduates as inputs to the development of teacher education enhancement program. 2015; 3(4):25-33.

35. Wright P. The instructions clearly state ... can't people read? Applied Ergonomics. 1981; 12(3):131-41. https://doi. org/10.1016/0003-6870(81)90002-8
36. Rahimi M, Katal M. The role of metacognitive listening strategies awareness and podcast-use readiness in using podcasting for learning English as a foreign language. Computer Human Behaviour. 2012; 28(4):1153-61. https:// doi.org/10.1016/j.chb.2012.01.025

37. Garrett P, Shortall T. Classroom Activities; 2002.

38. Ferido MB. The spiral progression approach in science. IRHE; 2013. p. 1-34.

39. Greengerg D, Zanetis J. The impact of broadcast and streaming video in education; 2012. p. 5.

40. MacInnes J. Statistics anxiety' a fairy tale for our times? Podcast; 2016.

41. Stewart DW, Panus PC, Hagemeier NE. An analysis of student performance with podcasting and active learning in a pharmacotherapy module. Currents in Pharmacy Teaching and Learning. 2013; 5(6):574-79. https://doi. org/10.1016/j.cptl.2013.07.004

42. Özdener N, Güngör Y. Effects of video podcast technology on peer learning and project quality. Procedia - Social and Behavioral Sciences. 2010; 2(2):2217-21. https://doi. org/10.1016/j.sbspro.2010.03.311 